\title{
O GLOBO E AS COTAS RACIAIS: UMA ANÁLISE DOS EDITORIAIS DO JORNAL (2003-2012)
}

\section{O GLOBO AND THE RACIAL QUOTAS: AN ANALYSIS OF THE NEWSPAPER EDITORIALS (2003 - 2012)}

Matheus de Carvalho Leibão'

RESUMO: $\mathrm{O}$ trabalho consiste em uma análise de editoriais do jornal $\mathrm{O}$ Globo que comentavam a questáo das cotas raciais no acesso ao ensino superior público no Brasil. A partir de uma leitura densa do material do jornal entre os anos de 2003 e 2012, destacam-se aqui os argumentos mais recorrentes utilizados pelo jornal na sua posição contrária à Lei de Cotas, encaminhada pelo governo federal e sancionada em 2012 por Dilma Rousseff. Ao final, é feita uma reflexão sobre os usos do passado pelos meios de comunicação, questão que é crucial para os historiadores que se dedicam ao estudo da imprensa no tempo presente.

Palavras-Chave: Cotas raciais, O Globo, História do tempo presente.

ABSTRACT: This paper consists on an analysis of newspaper editorials from $O$ Globo on the issue of racial affirmative actions in the access towards public universities in Brazil. Through a deep immersion on the material of that newspaper between the years of 2003 and 2012, we highlight the most recurrent pleas the newspaper published against the racial affirmative actions Law, which was forwarded by the federal government and approved by Dilma Roussef in 2012. Finally, we make a reflection on the uses of the past by the means of communication, a topic that is fundamental for the historians who study the press in the present time.

Keywords: Racial Affirmative Actions, O Globo, Present Time History.

\section{INTRODUÇÃO}

O presente estudo faz parte de uma pesquisa de mestrado em andamento que busca discutir como o jornal O Globo apresentou a temática das cotas raciais nas universidades públicas brasileiras. Como recorte temporal para a análise foi escolhido o período entre 2003, ano de início de implantação deste tipo de ação afirmativa pela UERJ até 2012, ano de positivação da lei de cotas em âmbito federal. Então, este artigo se concentrará na análise dos editoriais do jornal, a fim de entender quais foram os valores, ideias e argumentos que fizeram com que O Globo mobilizasse esse debate.

1 Mestrando em História pelo Programa de Pós-graduação em História da Universidade Estadual do Rio de Janeiro - UERJ. Bolsista Capes. E-mail: math3.carvalho@hotmail.com 
A política de cotas raciais, na perspectiva aqui adotada, promoveu um debate intenso na sociedade brasileira, no qual os meios de comunicação, em especial os grandes veículos da burguesia, buscaram enquadrar tal medida como polêmica. A partir deste enquadramento, pode-se verificar uma série de argumentaçôes acerca deste tipo de política pública na imprensa brasileira. Este debate, então, provocou uma intensa reflexão sobre a história das relaçóes raciais no Brasil, a identidade do povo brasileiro, os conceitos que deveriam guiar a educaçáo nacional, entre outros elementos.

Cabe aqui, então, situar a posição do jornal O Globo, a partir de seus editoriais. É importante ressaltar que ele faz parte do maior conglomerado de mídias do país, sendo, então, a maior empresa de comunicação brasileira no início do século XXI. A extensão das organizaçóes Globo abrange desde a mídia impressa, com revistas, jornais e até uma editora, passando pelo rádio (AM e FM) e pela televisão até o portal de notícias on-line mais popular do país. Verifica-se, então, um fenômeno que os especialistas na área de comunicação social chamam de propriedade cruzada (LIMA, 2011). Os editoriais exprimem a posiçáo do veículo, ou seja, como os proprietários do maior conglomerado de mídias do Brasil viam a proposta de política pública que visava incluir estudantes negros nas universidades.

Como bem destacaram Luiz Augusto Campos (CAMPOS, 2013), e Ilídio Medina Pereira (PEREIRA, 2011), em suas teses de doutorado, a posição de O Globo é contrária às cotas raciais. $\mathrm{O}$ veículo, então publicou uma serie de textos em que vários tipos de argumentos são levantados buscando convencer seus leitores de que esta medida não poderia ser benéfica para a sociedade brasileira. Buscarei elencar os argumentos mais recorrentes na discussão, enfatizando o lugar que a História ocupa neste debate.

É importante destacar que as cotas raciais são apenas um tipo de ação afirmativa entre as várias possíveis. No caso brasileiro, também houve uma série de cotas diferentes no ensino superior público, sendo o projeto mais comentado o projeto que culminou na aprovaçáo da lei n. ${ }^{\circ}$ 12.711/2012, também conhecida como Lei de Cotas. Ela, na verdade, náo estabelecia reserva de vagas exclusivamente para candidatos às universidades federais autodeclarados negros, pardos e indígenas, como boa parte da discussáo dos editoriais do jornal sugeria. A lei estabeleceu reserva de $50 \%$ das vagas das IFES para estudantes que haviam cursado todo o ensino médio em escolas públicas. Metade das vagas reservadas seriam destinadas a estudantes de baixa renda, havendo rum recorte racial tanto para as vagas de estudantes de escola pública de baixa rendo quanto para estudantes de escola pública independentemente dos rendimentos. Os recortes raciais variariam de estado para estado, levando em consideração a composição étnico-racial de cada unidade da federação. Portanto, as vagas reservadas a negros, pardos e índios seriam maiores na Bahia do que no Rio Grande do Sul, por exemplo. Havia, portanto, recortes de renda e de raça no projeto que foi sancionado por Dilma Rousseff em 2012. Outras universidades, estaduais e mesmo federais antes de 2012 já tinham alguns sistemas de ação afirmativa que poderiam ter como critério apenas o critério de renda, outras que contemplariam estudantes das escolas públicas, outras que adotavam critérios de auto declaração racial, etc. 
Quando falamos da rejeição do veículo da família Marinho às cotas, pode-se constatar uma verdadeira aversão a qualquer tipo de reserva de vagas nas universidades brasileiras. Ou seja, fosse o critério a renda, a origem escolar ou grupo racial em que se enquadrasse o estudante, ou até mesmo se tratando de projetos que buscavam integrar as três questóes, O Globo era contrário a todas. A não aceitação das cotas, neste sentido, tem como base ideológica a ideia de meritocracia.

Nas páginas do veículo onde constam editoriais comentando a questão das cotas, em quase todas elas fica destacada a preocupação de seus proprietários em relação ao mérito acadêmico, que deveria ser, segundo eles, o único critério de seleção para as universidades públicas. Este mérito, no caso, seria o de ter aprendido os conteúdos necessários para se conseguir boas notas nos exames vestibulares, o que para o veículo seria uma condição sine qua non para que os estudantes fizessem um curso superior de qualidade, e consequentemente, tivessem uma boa entrada em um mercado de trabalho cada vez mais dinâmico, competitivo e globalizado.

O segundo editorial que o jornal lança se colocando contrariamente às cotas no ano de 2003 já deixava clara a posição do veículo:

O debate fica mais profundo se tratar da fase posterior aos estudos. Ou seja, tratar da capacidade do formando beneficiado pelas cotas competir para ocupar um espaço nos estreitos mercados profissionais. Sem o acesso de todos — independentemente de cor, sexo e classe social - a uma escola eficiente no ciclo básico, ideias bem intencionadas de proteção deste ou daquele grupo na sociedade produzirão apenas frustraçôes. Um profissional sem qualificação, seja rico, pobre, preto ou branco, não tem espaço no mercado de trabalho. (O GLOBO, p. 6, 2003.)

Para O Globo, então, o vestibular seria um importante aferidor de capacidade não apenas para o ingresso no ensino superior, mas também na vida profissional. Caso o estudante chegasse "despreparado" à universidade — isto é, sem ter uma nota suficientemente boa nos exames de vestibular — nem a universidade, tampouco o esforço do estudante cotista para se manter no nível superior público poderiam ser capazes de reverter um "inevitável" fracasso destes estudantes. Ou seja, na visão exposta no jornal, estudante cotista seria sinônimo de aluno universitário com baixo rendimento, e, portanto, de trabalhador desqualificado. Então, percebe-se uma clara concepção mecânica do processo pedagógico por parte do jornal, que entendia que os alunos com notas mais altas nos vestibulares seriam necessariamente os melhores estudantes dos cursos universitários e os melhores profissionais do mercado de trabalho.

Também é importante notar que, como O Globo lança mão de argumentos contrários às cotas que valem para estudantes de escolas públicas de uma maneira geral e, contudo, foca muito mais em abordagens que tratam somente das cotas raciais, o veículo contribuiu - em um grau que é extremamente difícil precisar — para criar um estigma racial aos estudantes negros das universidades (cotistas ou não) que identificava nestes imagens de indivíduos despreparados, que não mereciam ocupar os bancos das universidades públicas. Este estigma fez com que os estudantes negros caíssem na categoria de "desacreditados", conceito esmiuçado por Daniela Valentim em sua tese de doutorado. (VALENTIM, 2012) 
Outro ponto importante a se notar a partir da crítica que O Globo fez às cotas baseando-se na ideia de mérito, é que tal ideia se apresenta tendo como referência uma entidade supostamente neutra, que não distinguiria, portanto, os seres humanos por raça, gênero, credo, etc.: o mercado. Ao reivindicar o mérito e o mercado como fundamentos básicos para sua oposição em relação às cotas raciais, o jornal busca construir uma autoimagem que é típica dos grandes veículos de comunicação burgueses: a imagem do jornal neutro ideologicamente. Em um editorial intitulado "Um equívoco", publicado em maio de 2004, esta tendência fica evidente:

A discussão é apaixonada por estar contaminada por ideologias. Mas há um ponto central do debate que merece ser analisado com um mínimo de sensatez: a qualidade do ensino. Sem que essa questão se torne prioritária, a política de cotas não gerará apenas injustiças no ingresso ao ensino superior. Patrocinará, também, distorçóes graves na formação profissional de geraçóes de brasileiros, com defeitos ruinosos para o país. (O GLOBO, p. 6, 2004) [Grifos nossos.]

O jornal, então busca construir uma imagem de si que está alheia às disputas ideológicas. Entretanto, cabe ao historiador buscar desnaturalizar essa imagem de veículo neutro e desinteressado. Como bem apontou István Meszáros, ainda que o período de educaçáo formal dos seres humanos, nas sociedades capitalistas, seja limitado a alguns poucos anos da vida da maioria dos indivíduos, o processo educacional faz parte de um processo que nos acompanha por toda a vida (MÉSZAROS, 2008, p. 81). Neste sentido, os meios de comunicação - mas não só eles - tem uma importância fundamental no processo de constituição das consciências humanas. ${ }^{2}$ Assim:

Quer os indivíduos particulares tenham ou não consciência disso, não podem sequer encontrar a mínima gota de "fundamento neutro" de valor em sua sociedade, muito embora a explícita doutrinação ideológica lhes garanta de forma enganosa o oposto, pretendendo - e convidando os indivíduos a se identificarem "autonomamente" com essa pretensão - que eles sejam plenamente soberanos em sua escolha dos valores em geral, assim como se afirma que eles são consumidores soberanos das mercadorias produzidas capitalisticamente, adquiridas com base nas escolhas soberanas nos supermercados controlados de modo cada vez mais monopolista. Tudo isso é uma parte integrante da educação capitalista pela qual os indivíduos particulares são diariamente e por toda parte embebidos nos valores da sociedade de mercadorias, como algo lógico e natural. (MÉSZAROS, 2008, p. 82)

É interessante notar os termos que surgem na passagem do jornal acima. Nela, ideologia e sensatez são enquadradas como antíteses. Portanto, quem se colocaria neste debate com base em algum tipo de ideologia náo estaria raciocinando friamente, algo que o jornal aparentava buscar fazer apesar das "paixóes" que o permeavam. Ou seja, ao evocar a "sensatez" para criticar a ideia das cotas, ${ }^{3} \mathrm{O}$ Globo confere uma denotação aos defensores desta política como "insensatos", já que, do ponto de vista do jornal, não seria plausível, sob hipótese alguma, a relativização da ideia do mérito acadêmico como único princípio

2 Vale lembrar que, na perspectiva aqui adotada, os meios de comunicação são encarados como importantes aparelhos privados de hegemonia.

3 O editorial em questão não especificava se estava se referindo a cotas raciais, sociais ou para estudantes de escolas públicas, ou mesmo as três justapostas, como no projeto que culminou na Lei de Cotas. 
norteador das seleçôes para o ensino superior público, buscando assim não apenas convencer seus leitores sobre sua oposição à lei de cotas, mas também, como lembrou Meszáros, de apresentar o mundo como ele é despindo-o de suas trajes ideológicas. Esta tendência fica mais visível em um outro editorial, já no ano de 2006, quando a proposta de Lei de Cotas tramitava na Câmara dos deputados:

Os grupos de pressão que querem aprovar as cotas a todo custo demonstraram, mais uma vez,
que pretendem manter à distância qualquer discussão racional, recorrendo em seu lugar a
palavras de ordem e à truculência contra seus opositores. Naturalmente, as toscas encenaçóes
e as vaias que marcaram a sessão na câmara deixam claro que esse lobby sabe que o projeto
dificilmente resistirá a um exame consistente. (O GLOBO, p. 6, 2006b)

A evocação da "razão" e a defesa do mérito acadêmico como único princípio norteador do acesso à universidade foram recursos argumentativos dos quais $\mathrm{O}$ Globo lançou mão para criticar qualquer tipo de ação afirmativa que buscasse inserir no ensino superior grupos subrepresentados - negros, índios, pobres, e/ou estudantes de escolas públicas. No entanto, interessa-nos aqui, particularmente, entender como o veículo se posicionou em relação às reservas de vagas para estudantes com base no conceito de raça. Então, buscarei elencar a seguir os principais argumentos utilizados pelo jornal para se opor especificamente às cotas raciais.

O primeiro deles indica que a ideia das cotas raciais seria uma pauta importada dos Estados Unidos. Segundo esta ideia, a história das relaçóes raciais naquele pais diferia em muitos aspectos da forma como os brasileiros se portavam em relaçáo às diferenças fenotípicas entre os seres humanos. Nos EUA, onde houve uma segregação racial sustentada pelo próprio Estado, inclusive com a proibição de casamentos inter-raciais, seria muito mais plausível introduzir o conceito de "discriminação positiva" na legislação. Tal situação, segundo O Globo, diferia fundamentalmente da formação social do povo brasileiro, marcada pela miscigenação racial e pela ausência de tensóes raciais. Portanto, a adoção de medidas "copiadas" dos EUA, geraria distorções, podendo, inclusive, despertar tensôes raciais que não existiam aqui.

Ainda dentro da concepção de "pauta importada", O Globo, apesar de indicar uma plausibilidade maior para a existência de açóes afirmativas raciais nos EUA do que no Brasil, em diversos editoriais aponta que a Suprema Corte daquele país havia imposto uma série de restriçóes a este tipo de política pública. Esta informação presente nos editoriais buscava, então, convencer o leitor de O Globo de que as cotas raciais seriam absolutamente descabidas para o Brasil e um tanto estranhas ou já defasadas mesmo para os EUA. Em um editorial intitulado "visão estreita", verifica-se a articulação deste argumento com o argumento do mérito: Importado dos Estados Unidos — onde a Suprema Corte já atenuou sua aplicação - esse tipo de política coloca em cheque o princípio imperativo do mérito, sem o que um ensino superior de qualidade é trágica ilusão. (O GLOBO, p. 6, 2005)

Outro argumento, que de alguma forma, foi articulado àquele que afirmava que as cotas tinham uma origem exógena da sociedade brasileira, afirmava que seria impossível 
definir com precisão quem seria ou não negro no Brasil. Os recursos utilizados neste tipo de argumento foram diversos.

Um deles recorria a estudos estatísticos do IBGE, mostrando haver uma tendência quase natural da população brasileira à miscigenação racial. Assim, em editorial com o título "Na contramão", O Globo afirmou:

No momento em que o IBGE revela o impulso que tomou a tendência de mestiçagem da população brasileira, fica mais evidente do que nunca como é contraproducente a ideia das açôes afirmativas, especificamente a criação das cotas raciais nas universidades. A intenção é a melhor possível: abrir para negros, pardos e índios melhores oportunidades de ascensão social; mas o artificialismo da proposta faz dela um verdadeiro tiro no pé.

De fato, quando vão desaparecendo as diferenças raciais no Brasil - a tal ponto que, de dois gêmeos idênticos, um foi aceito para ocupar vaga em cota na Universidade de Brasília sendo o outro rejeitado - já não é mais hora de insistir em diferenciar brasileiros pela cor da pele. $(\mathrm{O}$ GLOBO, p. 6, 2007b.)

Como pode se verificar, o jornal realiza uma verdadeira exaltação da mestiçagem como elemento fundamental das relaçóes raciais no Brasil de própria constituição do povo brasileiro. Portanto, a ideia de um Brasil como grande ícone da democracia racial aparece em diversas outras passagens. Em um editorial de 2 de abril de 2007, O Globo alertou para os perigos de se ver a questão das desigualdades em sua relação com o racismo: "Querer intoxicar a questão social do país com racismo, de qualquer espécie, é conspirar contra as bases de sustentação do contrato social brasileiro" (O GLOBO, p. 6, 2007a).

Outro argumento utilizado para se negar a possibilidade da identificação racial dos sujeitos foi tomado a partir das ciências biológicas e da antropologia. Como é consenso no meio científico ao menos desde meados do século XX, não é possível afirmar a existência de raças humanas do ponto de vista biológico ou psicológico. Como pontuou Claude Lévi-Strauss, "Quando procuramos caracterizar as raças biológicas mediante propriedades psicológicas particulares, afastamo-nos da verdade cientifica, quer a definamos de uma maneira positiva quer de uma maneira negativa." (LÉVI-STRAUSS, 1993, p. 328). Entretanto, como o próprio autor ressalta,

Mas a simples proclamação da igualdade natural entre todos os homens e da fraternidade que os deve unir, sem distinção de raças ou de culturas, tem qualquer coisa de enganador para o espírito, porque negligencia uma diversidade de fato, que se impóe à observação e em relação da qual náo basta dizer que não vai ao fundo do problema para que sejamos teórica e praticamente autorizados a atuar como se este não existisse. (LÉVI-STRAUSS, op. cit., p. 336)

O postulado do antropólogo francês nos ajuda a entender que o simples reconhecimento da igualdade formal entre os seres humanos não é suficiente para que todos os homens vivam em igualdade. Da mesma forma, o simples reconhecimento da inexistência de raças biológicas como geradoras de distinçôes culturais nas sociedades humanas também não basta para a erradicação do racismo e das desigualdades que o atravessam. Porém, tal observação não foi levada em consideração pelo jornal.

Isto quer dizer que a questão das desigualdades raciais é vista por $O$ Globo, no máximo como um resquício de uma sociedade escravocrata, não podendo ser combatida com 
políticas públicas que se baseassem no conceito de raça. A defesa de um ideal baseado na ideia de "democracia racial", entretanto, náo pode ser encarada pelo pesquisador com o mesmo viés romântico em que ele aparece no jornal. Como bem apontou Carlos Hasenbalg, ainda na década de 1970,

\begin{abstract}
Se o ideal do embranquecimento serviu para estabelecer um compromisso entre as doutrinas racistas do fim do século passado [XIX] com a realidade sócio-racial do país, a "democracia racial" como parte da auto-imagem nacional “... pode ser vista como um meio cultural dominante cujo principal efeito tem sido o de manter as diferenças inter-raciais inteiramente fora da arena política, como conflito apenas latente (LAMOUNIER, 1968, p.16)”. (HASENBALG; SILVA, 1988, p. 116).
\end{abstract}

Então, se considerarmos correta a interpretação de Hasenbalg, podemos entender a tentativa de $O$ Globo de manter as questóes sociais apartadas das questóes raciais como um artificio de geração de consenso que, na verdade, buscava a manutenção das estruturas de poder da sociedade brasileira. Dificilmente, em uma sociedade de classes, um dos principais veículos de comunicação da mesma - e portanto, uma das maiores empresas - veria com bons olhos uma forma de política vinda de movimentos sociais - que, nos editoriais de $O$ Globo aparecem como "grupos de pressão" que aparelhavam o executivo - e despontava como uma importante ferramenta de ascensão social de grupos marginalizados por sua condição social, sua origem escolar ou suas características fenotípicas.

Prova disso é que, diante da possibilidade de aprovação da lei de cotas a nível nacional, e do avanço de políticas de ação afirmativa adotadas em várias universidades antes de 2012, O Globo apontava tal medida como "demagógica" e "superficial", que náo atacava a raiz dos problemas das desigualdades brasileiras. Então, qual seria a solução proposta pelo jornal para se erradicar a questáo da desigualdade do acesso ao ensino superior? Em quase todos os editoriais, $O$ Globo defendeu a melhoria do ensino público brasileiro, que, segundo o jornal estaria, em termos qualitativos, muito distante do ensino das escolas particulares. Entretanto, o jornal náo explora de que formas o ensino de base das escolas públicas brasileiras poderia melhorar. Além disso o jornal defendeu iniciativas de ONGs - em especial a Educafro ${ }^{4}$ — que visavam preparar estudantes negros, pobres e/ou oriundos de escolas públicas para os exames através de cursinhos populares. Verifica-se entáo que o jornal apontava para saídas de difícil aplicação e/ou com resultados a médio e longo prazo.

Entretanto, como bem lembrou Petrônio Domingues:

Se tentarem convencer um jovem negro, vestibulando, de que ele tem que esperar a melhoria
do sistema educacional brasileiro... (daqui não se sabe quantos anos!) para poder realizar o
sonho de ingressar na universidade pública, a reaçáo dele vai ser de indignação. Afinal, ele
quer uma soluçáo para o problema hoje, e não deixar para amanhá ou perder de vista na linha
imaginária do tempo. (DOMINGUES, 2005, p. 170)

Então, para O Globo, não havia resposta para a demanda dos jovens negros de baixa renda a curto prazo, ao menos a partir do poder público. Aparentemente, deveriam eles

4 A Educafro é uma Organização não governamental liderada por Frei David Santos, cujo objetivo é ampliar o acesso de jovens estudantes negros no ensino superior — público ou privado. 
então, contentar-se com a subalternidade, para, quem sabe, um dia seus filhos ou netos pudessem competir nos vestibulares em pé de igualdade com os estudantes de mais afortunados de escolas privadas.

Outro argumento utilizado pelo jornal para combater as cotas raciais afirmava que elas seriam uma discriminação contra os brancos pobres do país. Uma vez que entendia-se que os problemas sociais enfrentados pelos negros, pardos e indígenas do Brasil seriam de ordem puramente socioeconômica, nada tendo a ver com os efeitos do racismo, seria injusto conceder uma reserva de vagas exclusivamente a estes segmentos. A oposiçáo a tal ideia foi tão forte a ponto jornal utilizar o termo apartheid para classificá-lo:

Quando se critica a proposta, o objetivo é impedir que haja um apartheid contra o branco pobre, um dos mais prejudicados pela ideia. Conforme alerta o documento encaminhado ao STF por 113 intelectuais, artistas, representantes de movimentos sociais e de sindicatos, as cotas, ao contrário do que se quer fazer crer, são elitistas, pois beneficiarão apenas uma franja da classe média, média/baixa, mantendo a grande massa de pobres, independentemente da cor, na margem do ensino. (O GLOBO, p. 6, 2008.)

Ou seja, ao identificar os problemas sociais enfrentados por brancos, negros e indígenas de baixa renda, $O$ Globo não leva em consideração - ao meu ver, de maneira intencional — um aspecto presente em diversas sociedades capitalistas com grande diversidade étnica-racial, em especial o Brasil: o fato de que $O$ racismo figura como um rastro, uma marca indelével da atualização promovida pelo capital das dominaçóes pretéritas (FONTES, 2010, p. 181). Desta forma, exclui-se a noção de uma das funçóes mais cruciais do racismo nos processos de dominação de classes no Brasil, que é o de acrescentar elementos culturais fundamentais para ampliação da extração de mais-valia. Este recurso, vale destacar, é historicamente utilizado pela burguesia brasileira. Como a própria Virgínia Fontes nos lembra,

Essa burguesia brasileira remói, resulta e promove contradições. No ruminar de antigas contradiçôes, atualiza as heranças das formas de dominação pregressas, das quais se instaura como herdeira. Assim, retoma os traços de uma colonização que a independência política jamais intentou seriamente ultrapassar, como as formas persistentes de racismo e a recriação de sua subalternidade no âmbito cultural... (FONTES, 2010, p. 312)

Desta forma, existe no interior da classe trabalhadora brasileira, em seus mais variados níveis de renda, uma espécie de hierarquia que é perpassada pelas questóes raciais, nas quais índios e negros são colocados em uma posição inferior. 5 Como o jornal O Globo simplesmente ignorou (propositalmente, insisto) este ponto, foi possível ver a questão do recorte racial dentro da lei de cotas como uma discriminaçáo aos brancos pobres, mesmo que no projeto de lei mais comentado pelo veículo constasse uma parte da reserva de vagas a este grupo. Vale lembrar que, via de regra, os jovens brasileiros brancos e de baixa renda estudam em escolas públicas.

A última passagem de $\mathrm{O}$ Globo que citei neste trabalho afirmava que as cotas raciais beneficiariam apenas uma parcela da classe média negra, o que subverteria a sua lógica

5 Neste caso, a discussão não se restringe apenas às questôes da discriminação racial, mas também às questôes de gênero. 
original. Este tipo de argumento ficou conhecido como creamy layer (FERES JÚNIOR; DAFLON, 2015). Como este argumento já foi suficientemente destrinchado por João Feres Júnior e Verônica Daflon, não me alongarei na análise do mesmo. Entretanto, vale ressaltar dois pontos levantados pelos autores, que, de alguma forma, se articulam.

Primeiramente, cabe destacar que, apesar do argumento ter surgido na Índia, o seu principal propagador foi o economista norte-americano Thomas Sowell. Segundo Daflon e Feres Júnior,

Sowell é titular da cátedra Milton Friedman na Universidade de Stanford e um ícone do pensamento conservador americano. Autor do livro Affirmative action around the world: an empirical study (Sowell, 2004), que é um verdadeiro manifesto contra essas políticas, Sowell deslinda uma miríade de argumentos contra políticas de ação afirmativa e tem como ponto principal a tese de que elas foram experiências fracassadas nos países que as implantaram (FERES JÚNIOR; DAFLON, 2015, p. 243)

A contextualização feita pelos autores nos permite entender melhor o lugar social de onde partem estas ideias, para que não se caia no mesmo equívoco teórico cometido por Monique Franco (FRANCO, 2011). O trabalho da autora levanta uma série de argumentos pró e anti-cotas como se eles partissem de uma preocupação moral de intelectuais com estas questóes e nada (ou pouco) tivessem a ver com o lugar que cada um ocupava na sociedade.

Outro ponto fundamental a ser lembrado é que, ainda segundo Daflon e Feres Júnior, o argumento de Thomas Sowell carece de uma fundamentação empírica que seria fundamental na composição deste debate (FERES JUNIOR; DAFLON, 2015). Além disso, a suposta experiência fracassada de outros países náo implicaria mecanicamente o fracasso das cotas raciais na sociedade brasileira. Desta forma, pode-se verificar uma contradiçáo na discussão proposta por $O$ Globo, uma vez que, se as cotas não teriam validade por ser uma "pauta importada" dos EUA, a crítica do jornal, por sua vez, seria igualmente importada dos EUA, mais precisamente de um dos mais conservadores acadêmicos daquele país.

A justiça também náo escapou de eventuais textos de $O$ Globo. Segundo o jornal, a proposta do governo federal não teria compatibilidade com a constituição do país, devendo, portanto, ser rejeitada. É interessante notar que esta argumentação também se dá no sentido de criticar qualquer tipo de reserva de vagas, náo apenas as que tinham recorte racial. Desta forma, a argumentação da inconstitucionalidade das cotas anda lado a lado com a argumentaçáo mais ampla do jornal, que se ancorava na ideia do mérito acadêmico. Tal relação fica bem explícita em um editorial intitulado "Bom-mocismo":

Num clima de bom-mocismo que anda predominando ultimamente no país - talvez para afastar atenção dos desastres que atingiram todos os níveis de poder - a Câmara dos Deputados acaba de aprovar o projeto que reserva $50 \%$ de vagas nas universidades públicas a alunos vindos de escolas públicas, negros, pardos e índios.

O projeto é uma violência, e passa por cima de todas as nuances que deveriam prevalecer num assunto como a educação. Começa desautorizando a Constituição, segundo a qual "o acesso aos níveis mais elevados de ensino e pesquisa se dará de acordo com a capacidade de cada um" (O GLOBO, p. 6, 2006a). 
Os textos que evocavam a inconstitucionalidade das cotas raciais se fizeram presentes no jornal até abril de 2012, quando o STF terminou o julgamento desta questão, decidindo que a reserva de vagas nas universidades tinha base constitucional. Uma vez que o órgão superior decidiu pela legalidade das cotas, o jornal não tornou em alegar sua ilegalidade. $\mathrm{Na}$ interpretaçáo aqui adotada, não considero que tal fato tenha se dado por um "respeito" à decisão do Supremo. Na verdade, como um jornal influente, lido pelas camadas médias e altas da sociedade brasileira, inclusive os membros do judiciário muito embora o veículo tenha circulaçáo maior no Rio de Janeiro - O Globo buscava convencer os magistrados de sua posição. Neste sentido, é possível estabelecer uma interpretação que encara o jornal como um partido político. Esta concepção não está ancorada na ideia que tradicionalmente se tem de partidos políticos - como aquelas instituiçóes que disputam eleiçóes nas democracias contemporâneas - mas sim na teoria de Estado Ampliado desenvolvida por Antonio Gramsci.

Segundo o filósofo italiano, que se opunha à teoria liberal do Estado, identificar Estado e Sociedade civil como polos antagônicos de um tecido social não levava a uma compreensão acertada das dinâmicas das relaçóes. Em sua concepção, o Estado é a justaposição de parte da sociedade civil, a partir de seus aparelhos privados de hegemonia (escolas, igrejas, sindicatos, associações empresariais, meios de comunicação, etc.) com a sociedade política, isto é, as forças armadas, a polícia, os poderes legislativos, executivo e judiciário. A uniáo entre parte da sociedade civil e os aparelhos coercitivos do Estado formam o que Gramsci chama de Estado Ampliado, que é capaz de garantir a dominação de uma classe ou fração de classe sobre outras, a partir de uma combinação entre coerção e consenso, que estabeleceria então a hegemonia de certos grupos em relação a outros (GRAMSCI, 2014, p. 21). Nesse sentido, as entidades da sociedade civil que tentassem e/ ou conseguissem estabelecer um elo entre o grupo representado por elas e o Estado, teriam uma função próxima a de um partido político. Como pontuou o pensador italiano,

\footnotetext{
Um comerciante não ingressa num partido político para comerciar, nem um industrial para produzir mais e com custos reduzidos, nem um camponês para aprender novos métodos de cultivara terra, ainda que alguns aspectos destas exigências do comerciante, do industrial, do camponês possam ser satisfeitos no partido político. [...] Para estas finalidades, dentro de certos limites, existe o sindicato profissional, no qual a atividade econômico-corporativa do comerciante, do industrial, do camponês encontra seu quadro mais adequado. No partido político, os elementos de um grupo social econômico superam este momento de seu desenvolvimento histórico e se tornam agentes de atividades gerais, de caráter nacional e internacional. (GRAMSCI, 2014, p. 25)
}

Desta forma, a função de O Globo, levando em consideração seu peso e relevância na sociedade brasileira, não é apenas a produção de jornalismo desinteressado e neutro ideologicamente, como o próprio se pretende mostrar - para garantir o que Miquel Rodrigo Alsina chamou de "contrato fiduciário" (RODRIGO ALSINA, 2009). O jornal também opera no sentido de exercer pressão sobre os três poderes, em especial o Executivo 
e o Legislativo6, mas também em relação ao judiciário. Um dos mecanismos que possibilita o jornal a operar desta forma é que ele se coloca como um importante porta-voz da opinião pública, à qual os representantes legais devem satisfaçôes. Entretanto, a "opinião pública" do jornal náo é formada por todo o público, o que acaba por conferir um poder de influência maior aos grandes conglomerados comunicacionais. Ou seja, o jornal estava mais preocupado em informar os magistrados sobre o que seria a "opiniáo pública" do que de fato construí-la com o público — seja lá quem fosse o público.

Por fim, cabe destacar o lugar ocupado pela História na discussão proposta pelo veículo. Como a questão das desigualdades raciais no Brasil contemporâneo tem suas origens na ordem escravocrata que foi imposta no processo de colonização a partir do século XVI, tornar-se-ia praticamente impossível ignorar as contribuiçóes da historiografia no debate sobre as cotas raciais. Entretanto, nos editoriais do veículo, ela aparece com uma frequência muito frágil.

O principal ponto em que a História é mobilizada nos editoriais de O Globo se dá do ponto de vista comparativo. Buscando legitimar a sua crítica às cotas raciais como uma política importada dos EUA, O Globo afirmou uma série de vezes as diferenças entre a História do Brasil e a daquele país, em especial o que tange às relaçóes raciais no pós-abolição.

A existência de uma segregação racial oficial no país norte-americano, sustentada pelas Jim Crow laws, segundo O Globo, fazia com que o reconhecimento da desigualdade entre brancos e negros que houve nos EUA qualificasse a história das relaçóes raciais brasileiras como mais branda, flexível, mais integrada. Nesse sentido, o jornal fazia uma verdadeira exaltação da mestiçagem, que seria "a base do contrato social brasileiro". A inexistência de uma segregação oficial, sobretudo a partir da instituição da república, com o reconhecimento da igualdade formal, então era visto como um ponto positivo na história da formação da nação.

Outro argumento em que $\mathrm{O}$ Globo lança mão de um argumento com base histórica foge às comparaçóes com o racismo institucionalizado nos EUA. O jornal lançou mão de dados — alguns um tanto descontextualizados — para relativizar a proeminência social dos brancos em detrimento dos negros no período da escravidão. Entáo, o veículo fez questão de lembrar da existência de senhores de escravos negros na história do Brasil e o fato de os próprios africanos venderem seus conterrâneos como escravos para os portugueses, como pode-se perceber neste editorial de 2 de abril de 2007, quando o jornal criticava uma declaração da Ministra da SEPPIR, que afirmara compreender a insurgência de um negro contra um branco:

A visão da ministra é tão carregada de ideologia que releva o racismo caso ele seja praticado por um negro contra um branco, mesmo sendo um crime previsto na legislação brasileira. Como justificativa — estava implícito — , ela aponta as supostas dívidas históricas da escravidão quando, registre-se, também negros atuaram como senhores de escravos. Escravos estes, por

6 Pois estes estão sujeitos à avaliação popular que ocorre através do voto. 
sinal, subjugados por tribos negras na África e vendidos por elas aos mercadores (O GLOBO, 2007b, 6).

Como boa parte dos textos publicados no próprio jornal em favor das cotas raciais recorriam à História para legitimar suas posiçóes — sobretudo entendendo as cotas como uma reparação de dívida histórica - acredito que O Globo optou por apenas tangenciá-la com o objetivo de marcar uma distinçáo entre a sua posição e a opiniáo de acadêmicos, políticos e artistas que tiveram algum espaço neste veículo. Enquanto os seus defensores, portanto, apareceriam com uma grande preocupaçáo com o passado, o jornal se mostrava com uma preocupação com o presente e o futuro.

No entanto, nas vezes em que a História foi pinçada pelo jornal, ele fez questão de lembrar da exceção à regra da ordem escravocrata no Brasil. Quando se afirma que também os negros foram responsáveis pelo infortúnio da escravidão, a História é mobilizada a fim de dar vazão a uma motivação política conservadora. Uma vez que negros também escravizaram, as cotas náo fariam sentido, independentemente do fato de que a posse de escravos por homens de cor e a própria ascensão social dos mesmos durante a vigência da escravidão e no pós-abolição fosse bastante dificultada por processos de descriminação racial, o que fazia com que estes fatos tivessem alcance totalmente limitado, como bem demonstraram Carlos Hasenbalg e Nelson do Valle e Silva (HASENBALG; SILVA, 1988).

Além disso, o jornal opera um deslocamento da identidade negra para a África précolonial. O reconhecimento de diversos indivíduos como negros simplesmente inexistia na África na época das grandes navegaçóes. Ela, na verdade, se construiu a partir da diáspora, num processo que fez com que quem descobrisse a África no Brasil, não tenha sido os europeus, mas os próprios africanos, como afirmou Robert Slenes (SLENES, 1991). Obviamente, seria ingenuidade pensar nesse equívoco como um descuido historiográfico do jornal, ainda que ele não fosse constituído por historiadores. De certo, este deslocamento da identidade negra, tal qual a descontextualização das relaçóes raciais no período escravocrata, configura-se num processo bastante comum nos meios de comunicaçáo e no debate político de uma maneira geral que costumou chamar de "usos do passado". Nesse sentido, estou de acordo com Marialva Barbosa quando a autora defende que a própria apropriação contemporânea da noçáo de historicidade advém dessas intensas figuraçóes do passado que aparecem cotidianamente nos meios de comunicação (BARBOSA, 2008, 84).

Então, a título de síntese, podemos dizer que O Globo, a partir de seus editoriais, promoveu uma campanha política aberta contrária às cotas, não apenas aquelas que previam recortes de tipo racial, mas qualquer inclusão com bases sociais. Desta forma, entendo aqui, que ao lançar mão de uma série de argumentos para criticar a proposta de política pública que buscavam diminuir a importância do movimento negro, defender o mérito como um princípio absoluto e prever um inevitável fracasso dos estudantes cotistas nas universidades públicas do Brasil, o jornal agiu como um partido político, uma vez que se valeu de seu prestigio a fim de pressionar o governo federal, a oposição e até mesmo o judiciário para a revogação da proposta. 
Para a felicidade de muitos brasileiros marginalizados, O Globo saiu derrotado. Entretanto, as suas argumentaçôes contrarias às ainda encontram eco na sociedade brasileira, quatorze anos depois do início deste tipo de ação afirmativa. Este fato deve atentar os historiadores da imprensa e demais estudiosos dos meios de comunicaçáo para que não se caia numa falsa dicotomia, em que, por um lado, enxerga-se a mídia com poderes maiores do que ela efetivamente possui, e por outro, tende a minimizar a sua importância nos seus processos de disputa de hegemonia. 


\section{REFERÊNCIAS}

BARBOSA, Marialva. Meios de comunicação e usos do passado: temporalidade, rastros e vestígios e interfaces entre Comunicação e História. In: RIBEIRO, Ana Paula Goulart; HERSCHMANN, Micael (Orgs.). Comunicaçáo e História: interfaces e novas abordagens. Rio de Janeiro: Globo Universidade/Mauad X, 2008. Cap. 5. pp. 83-96.

CAMPOS, Luiz Augusto \& FERES JÚNIOR, João. O Globo e as ações afirmativas: dez anos de cobertura (2001-2011). Textos para discussão GEMAA (IESP-UERJ), Rio de Janeiro, n. 2, pp. 1-18, 2013.

DOMINGUES, Petrônio. Ações afirmativas no Brasil: o início de uma reparação histórica. Revista brasileira de educação, n. 29, pp. 164-177, maio 2005.

FERES JÚNIOR, João; DAFLON, Verônica Toste. A nata e as cotas raciais: genealogia de um argumento público. Opiniáo Pública, Campinas, v. 21, n. 2, pp.238-267, ago. 2015.

FONTES, Virgínia. O Brasil e o capital-imperialismo: teoria e história. 2. ed. Rio de Janeiro: Editora Ufrj, 2010.

FRANCO, Monique. Espectros da mídia: políticas afirmativas ou políticas de piedade? O sofrimento do outro no contexto do "último homem". Rio de Janeiro: Revan, 2011.

GRAMSCI, Antonio. Cadernos do cárcere: Os intelectuais. O princípio educativo. Jornalismo. 7. ed. Rio de Janeiro: Civilização brasileira, 2014. 2 v.

HASENBALG, Carlos A.; SILVA, Nelson do Valle. Estrutura Social, Mobilidade e Raça. 7. ed. São Paulo: Vértice, 1988. Cap. 4, pp. 115-143.

LÉVI-STRAUSS, Claude. Antropologia estrutural - dois. Rio de Janeiro: Tempo Brasileiro, 1993. 4 ed.

LIMA, Venício. Regulação das comunicaçóes: história, poder e direitos. São Paulo: Paulus, 2011.

MESZÁROS, István. A educação para além do capital. 2. ed. São Paulo: Boitempo, 2008.

PEREIRA, Ilídio Medina. Debate público e opiniáo da imprensa sobre a política de cotas raciais na universidade pública brasileira. 2011. $238 \mathrm{f}$. Tese (Doutorado). Curso de Comunicação Social, Faculdade de Biblioteconomia e Comunicaçáo, Universidade Federal do Rio Grande do Sul, Porto Alegre, 2011.

RODRIGO ALSINA, Miquel. A construção da notícia. Petrópolis: Vozes, 2009.

SLENES, R. Malungu, ngoma vem! África coberta e descoberta do Brasil. Revista USP, n. 12, dez./jan./fev. 1991

VALENTIM, Daniela Frida Drelich. Ex-alunos negros cotistas da UERJ: os desacreditados e o sucesso acadêmico. Rio de Janeiro: Quartet/FAPERJ, 2012. 


\section{Fontes}

O GLOBO, Rio de Janeiro, p. 6, 02 jun. 2003.

O GLOBO. Rio de Janeiro, p. 6, 20 maio 2004,

O GLOBO. Rio de Janeiro, p. 6, 29 dez. 2005.

O GLOBO. Rio de Janeiro, p. 6, 10 fev. 2006.

O GLOBO. Rio de Janeiro, p. 6, 27 abr. 2006.

O GLOBO. Rio de Janeiro, p. 6, 02 abr. 2007.

O GLOBO. Rio de Janeiro, p. 6, 11 jun. 2007.

O GLOBO. Rio de Janeiro, p. 6, 18 maio 2008. 